\section{Grafted Coffee Increases Yield and Survivability}

\author{
Roxana Myers ${ }^{1}$, Andrea Kawabata ${ }^{2}$, Alyssa $\mathrm{Cho}^{3}$, \\ and Stuart T. Nakamoto ${ }^{4}$
}

Additional index words. Coffea arabica, Coffea liberica, coffee decline, grafting, kona coffee, Meloidogyne konaensis, root-knot nematode

Summary. Kona coffee root-knot nematodes (Meloidogyne konaensis) cause severe declines in 'Kona Typica' arabica coffee (Coffea arabica) trees in Hawaii. Defoliation and destruction of the root system result in significant yield losses and can kill the host. Grafting with other coffee ( Coffea) species that exhibit tolerance to kona coffee root-knot nematodes is a viable solution for mitigating damage in the field. An infested field was established in 2006 with 'Kona Typica' scions grafted on seven accessions of promising rootstock and nongrafted 'Kona Typica' as the control. Four grafted trees of each accession were planted per plot with four repetitions. Yield data were assessed for the 2016-17, 2017-18, and 2018-19 seasons. Three liberica coffee (Coffea liberica) accessions ['Arnoldiana' ('Arnoldiana' 1 and 'Arnoldiana' 2), 'Dewevrei', and 'Fukunaga' 1], demonstrated higher yields of coffee cherry compared with nongrafted 'Kona Typica' in the 2016-17 season. In the 2017-18 and 2018-19 seasons, five accessions of liberica and 'Nemaya' robusta coffee (Coffea canephora) exhibited higher cherry yields than 'Kona Typica'. Plant vigor was greater in trees grafted on 'Arnoldiana' and 'Fukunaga' compared with other accessions and nongrafted 'Kona Typica', with taller trees, higher vertical branches, thicker trunk circumferences, and overall better health. After 13 years in the field, nongrafted 'Kona Typica' showed the highest mortality, with $81 \%$ of trees lost. Liberica rootstocks performed consistently well in the presence of kona coffee root-knot nematodes, with the healthiest trees, highest yields, and least mortality of the coffee species evaluated.

Received for publication 2 Dec. 2019. Accepted for publication 12 Apr. 2020.

Published online 11 May 2020

${ }^{1}$ United States Department of Agriculture, Agricultural Research Service, Daniel K. Inouye U.S. Pacific Basin Agricultural Research Center, 64 Nowelo Street, Hilo, HI 96720

${ }^{2}$ University of Hawaii at Manoa, Department of Tropical Plant and Soil Sciences, 79-7381 Hawaii Belt Road, Kealakekua, HI 96750

${ }^{3}$ University of Hawaii at Manoa, Department of Tropical Plant and Soil Sciences, 875 Komohana Street, Hilo, HI 96720

${ }^{4}$ University of Hawaii at Manoa, Department of Human Nutrition, Food and Animal Sciences, 1955 East-West Road, Honolulu, HI 96822

We thank Cathy Mello, Jen Burt, Marc Meisner, Nick Yamauchi, Matt Miyahira, and the coffee harvesting crew for their assistance. We also thank the University of Hawaii, College of Tropical Agriculture, and Human Resources staff who established and maintained the field plot over the 13-year period, and Dr. Scot Nelson and Virginia Easton-Smith, who initiated the trial.

Mention of trade names or commercial products in this publication is solely for the purpose of providing specific information and does not imply recommendation or endorsement by the U.S. Department of Agriculture. USDA is an equal opportunity provider and employer.

R.M. is the corresponding author. E-mail: roxana. myers@usda.gov.

This is an open access article distributed under the $\mathrm{CC}$ BY-NC-ND license (https://creativecommons.org/ licenses/by-nc-nd/4.0/).

https://doi.org/10.21273/HORTTECH04550-20
$\mathrm{R}$ oot-knot nematodes (Meloidogyne sp.) adversely affect yields of arabica coffee (Coffea arab$i c a)$ in many coffee-growing regions. In Kona, HI, kona coffee root-knot nematodes [Meloidogyne konaensis (Eisenback et al., 1994)] are extremely pathogenic to 'Kona Typica' arabica trees, causing a disease known as coffee decline (Serracin et al., 1999). This cultivar is known commercially as Kona Typica, although it has been referred to as Guatemalan in Hawaii for the last 100 years. Nematodeinfested trees show symptoms similar to nutrient and water deficiencies, such as leaf yellowing and flagging, followed by defoliation and even tree death. Underground, root galling and necrosis occur. The subsequent lack of feeder roots and overall destruction of the root system result in significant yield losses.
Grafting is a viable solution for mitigating damage caused by rootknot nematodes in coffee orchards. Cleft grafts are created with scions of arabica coffee seedlings at the hypocotyledon stage and a coffee species conferring resistance or tolerance to plant-parasitic nematodes as rootstocks (Reyna, 1966). Promising coffee species that can be used as rootstock typically have more vigorous root development, even in the presence of plant-parasitic nematodes (Cabos et al., 2010).

Robusta coffee (Coffea canephora) is widely used as rootstock in Central America and South America. The nematode-resistant 'Nemaya' was developed through a series of controlled crosses between promising cultivars that showed resistance or tolerance to root-knot nematodes and lesion nematodes [Pratylenchus sp. (Bertrand et al., 2000)]. 'Nemaya' expressed $64 \%$ resistance to southern root-knot nematodes (Meloidogyne incognita) and $78 \%$ resistance to a root-knot nematode species from El Salvador. When inoculated with kona coffee root-knot nematodes, 'Nemaya' demonstrated increased growth, healthier root systems, and less nematode reproduction compared with 'Kona Typica' (Cabos et al., 2010).

In Brazilian coffee plantations heavily infested with root-knot nematodes, 'Apoata' robusta coffee (IAC 2258 ) is used as a rootstock (Campos and Villain, 2005). Even with high initial populations of paraná coffee root-knot nematodes (Meloidogyne paranaensis), 'Apoata' maintains its strong level of resistance (Andreazi et al., 2015). Grafting onto 'Apoata' rootstock in nematode-infested fields resulted in 55\% higher yields compared with yields from susceptible cultivars (Barbosa et al., 2014).

Although liberica coffee (Coffea liberica) is not as widely used, using 'Fukunaga' ('Dewevrei') as a rootstock in Hawaii has been an effective management technique for controlling kona coffee root-knot nematodes

\begin{tabular}{llll}
\hline $\begin{array}{l}\text { Units } \\
\begin{array}{l}\text { To convert U.S. to SI, } \\
\text { multiply by }\end{array}\end{array}$ & U.S. unit & SI unit & $\begin{array}{l}\text { To convert SI to U.S., } \\
\text { multiply by }\end{array}$ \\
\hline 0.3048 & $\mathrm{ft}$ & $\mathrm{m}$ & 3.2808 \\
2.54 & inch(es) & $\mathrm{cm}$ & 0.3937 \\
0.4536 & $\mathrm{lb}$ & $\mathrm{kg}$ & 2.2046 \\
28.3495 & $\mathrm{oz}$ & $\mathrm{g}$ & 0.0353
\end{tabular}


(Schmitt et al., 2001). The rootstock was named 'Fukunaga' by University of Hawaii researchers in honor of Edward Fukunaga, a previous superintendent of the Kona Research Station (Kainaliu, HI) (Bittenbender et al., 2001). A 1.4-fold to 2.6-fold reduction in the kona coffee rootknot nematode population was detected when the 'Fukunaga' rootstock was used (Zhang and Schmitt, 1995). Higher yields and more robust root systems were also observed in infested field plantings of 'Kona Typica' grafted on 'Fukunaga' compared with nongrafted controls (Schmitt et al., 2001). The accessions were imported in the 1950s from the Instituto Agronomico do Campinas (Campinas, Brazil) and screened at the University of Hawaii's College of Tropical Agriculture and Human Resources Kona Research Station in Kainaliu, HI (Bittenbender et al., 2001). 'Arnoldiana' was also imported at that time, along with six other coffee species.

Unfortunately, open pollination of robusta and liberica coffee can significantly lower nematode resistance levels when progeny segregate for nematode susceptibility (Bertrand et al., 2000). A survey of coffee plantations in Espírito Santo, Brazil, found no differences in parasitism by root-knot nematodes of arabica and robusta coffee in the field (Barros et al., 2014). Although it was presumed by growers that all robusta coffee cultivars are resistant to rootknot nematodes, some cultivars demonstrated susceptibility to root-knot nematodes.

In addition to outcrossing, levels of resistance to different root-knot species can vary among coffee cultivars, and there is the potential for root-knot nematode populations to overcome single resistance genes over time. Continued evaluation of additional sources of host plant resistance is recommended to ensure long-term management of root-knot nematodes in Hawaii (Serracin and Schmitt, 2002). An investigation was conducted at a field plot infested with kona coffee root-knot nematodes and planted with 'Kona Typica' trees grafted on seven cultivars of promising rootstock material compared with a control (nongrafted 'Kona Typica'). The objective of this study was to revisit that field plot and evaluate the long-term effects of these rootstocks on coffee yield and tree health under field conditions.

\section{Materials and methods}

Field establishment. For the original investigation, the field was established in 2006 at the Kona Research Station (Kainaliu, HI). Potted 'Orange Pixie' tomato (Solanum lycopersicum) plants were inoculated with kona coffee root-knot nematode eggs collected from coffee roots in an adjacent field. Thirty days after inoculation, the roots were removed, finely chopped, and distributed uniformly throughout the field in a water slurry. The treatments included seven rootstocks that had the potential for resistance or tolerance to kona coffee root-knot nematodes and a control (nongrafted 'Kona Typica') (an eighth rootstock, 'Panamanian Dewevrei' liberica coffee, failed for unknown reasons and was subsequently replaced by placeholders). The rootstocks included two accessions of 'Fukunaga', two accessions of 'Arnoldiana', and one accession each of 'Nemaya', 'Apoata', and 'Purpurascens' arabica. Rootstocks were propagated by seed. 'Kona Typica' scions were grafted onto the rootstocks in 2005 . Nongrafted 'Kona Typica' was also propagated by seed. The field was planted in a randomized complete block design with four replications and four trees per replication (16 trees per treatment). At the time of the current study, two trees or scions had died, leaving 15 trees for two of the treatments. Supplemental irrigation was provided only until the trees were established. The entire plot was treated uniformly for fertilization, pest control, and other crop management activities.

All trees were stumped 46 to 61 $\mathrm{cm}$ from the ground in 2015. Emerging new verticals were reduced to four or fewer per stump later that year by the station staff. All remaining productive verticals were of similar age at the initiation of data collection in 2016.

Field populations of kona coffee root-knot nematodes were confirmed to be increased in 2019 by planting 'Orange Pixie' tomato plants randomly throughout the field next to grafted and nongrafted trees. Plants were removed after one or two nematode generations. Kona coffee root- knot nematode eggs were recovered in an average density of 3029 eggs per gram of tomato root.

YIELD DATA. The yield per tree of ripe, pulpable berries was collected at 19- to 21 -d intervals during the harvest season in 2016-17, 2017-18, and 2018-19. Berries were harvested, bagged, and weighed (kilograms) for each tree. Harvests were then aggregated by rootstock accession for further quality analyses. At the end of the season, the field was strip-picked to follow the recommended integrated pest management practice of sanitizing the field to prevent continued coffee berry borer development and reproduction (Kawabata et al., 2017).

Growth DATA. Plant growth data were collected in 2016 and 2017. The circumference and diameter of the trunk (centimeters) were measured for each tree. Overall tree height (meters) and the height of the tallest vertical (centimeters) were evaluated. A health rating based on a scale of 0 to 5 was assigned for each tree, with 0 being morbid and 5 representing optimal health.

\section{Results}

Over the 4-year pruning cycle, both accessions of 'Arnoldiana' produced the greatest amount of coffee cherry of all the rootstocks evaluated. Five of the grafted rootstocks (the liberica accessions and 'Nemaya') outperformed nongrafted 'Kona Typica' in the last two harvest seasons (Table 1). The four liberica accessions and 'Nemaya' had yields that were higher than those of 'Apoata', 'Purpurascens', and 'Kona Typica' in the 2018-19 harvest season $(P \leq 0.05)$. 'Fukunaga' 1, 'Arnoldiana' 1, 'Arnoldiana' 2, and 'Nemaya' had greater yields than 'Apoata', 'Purpurascens', and 'Kona Typica' in the 2017-18 harvest season $(P \leq 0.05)$. In the 2016-17 harvest season, 'Fukunaga' 1, 'Arnoldiana' 1, and 'Arnoldiana' 2 were the only grafted accessions that differed from the nongrafted 'Kona Typica' $(P \leq 0.05)$, although this is thought to be more a result of the pruning style instead of rootstock performance. In the 201819 harvest season, 'Arnoldiana' 1 had the highest red cherry yields of 9.8 $\mathrm{kg} /$ tree, whereas 'Arnoldiana' 2 had the greatest yields in 2017-18, at $10.9 \mathrm{~kg} /$ tree. In the first harvest season, trees grafted on 'Arnoldiana' 
1 had the highest yields, followed by 'Fukunaga' 1. Nongrafted 'Kona Typica' was the lowest producer in all harvest seasons, followed by 'Purpurascens' and 'Apoata'.

The trunk circumference was different for all grafted accessions (26$30 \mathrm{~cm}$ ) and the ungrafted control (19 $\mathrm{cm})$ in $2017(P \leq 0.05)$, with the exception of 'Apoata' $(26 \mathrm{~cm})$, which was not significantly different from the control. A similar trend was observed in 2016, with grafted trunks ranging from 24 to $27 \mathrm{~cm}$ compared with nongrafted 'Kona Typica' at 16 $\mathrm{cm}(P \leq 0.05)$. Both accessions of 'Arnoldiana' had the largest trunk circumference in 2017 and 2016.

In 2016, all accessions were taller $(1.8-2.2 \mathrm{~m})$ than 'Kona Typica' $(1.3 \mathrm{~m})(P \leq 0.05)$. 'Arnoldiana' 2 $(2.2 \mathrm{~m})$ was taller than 'Purpurascens' $(1.8 \mathrm{~m})$ and 'Apoata' $(1.8 \mathrm{~m})$.

Table 1. Coffee cherry yields for 'Kona Typica' arabica coffee grafted on rootknot nematode-tolerant rootstocks of liberica, robusta, or arabica coffee and nongrafted 'Kona Typica' planted in a root-knot nematode-infested field 11-13 years prior.

\begin{tabular}{|c|c|c|c|}
\hline \multirow[b]{2}{*}{ Cultivar } & \multicolumn{3}{|c|}{ Yield $(\mathrm{kg} / \text { tree })^{\mathrm{z}}$} \\
\hline & 2016-17 & $2017-18$ & $2018-19$ \\
\hline Fukunaga 1 & $3.8 \mathrm{a}^{\mathrm{y}}$ & $9.6 \mathrm{a}$ & $7.7 \mathrm{a}$ \\
\hline Fukunaga 2 & $2.3 \mathrm{abc}$ & $7.1 \mathrm{ab}$ & $9.1 \mathrm{a}$ \\
\hline Arnoldiana 1 & $3.5 \mathrm{ab}$ & $9.1 \mathrm{a}$ & $9.8 \mathrm{a}$ \\
\hline Arnoldiana 2 & $4.0 \mathrm{a}$ & $10.9 \mathrm{a}$ & $9.4 \mathrm{a}$ \\
\hline Nemaya & $2.3 \mathrm{abc}$ & $8.4 \mathrm{a}$ & $8.3 \mathrm{a}$ \\
\hline Apoata & $1.8 \mathrm{abc}$ & $3.1 \mathrm{bc}$ & $2.9 \mathrm{~b}$ \\
\hline Purpurascens & $0.7 \mathrm{bc}$ & $3.2 \mathrm{bc}$ & $2.5 \mathrm{~b}$ \\
\hline Kona Typica & $0.0 \mathrm{c}$ & $0.2 \mathrm{c}$ & $0.0 \mathrm{~b}$ \\
\hline
\end{tabular}

${ }^{\mathrm{z}} 1 \mathrm{~kg}=2.2046 \mathrm{lb}$.

${ }^{\mathrm{y}}$ Totals with the same letter were not significantly different according to the Tukey-Kramer highly significant difference test $(P>0.05)$.

Table 2. Mean vertical heights and plant health ratings of 'Kona Typica' arabica coffee grafted on root-knot nematode-tolerant rootstocks of liberica, robusta, or arabica coffee and nongrafted 'Kona Typica' planted in a root-knot nematodeinfested field 12 years prior (2017). Percent survivability was recorded in 2018 , 13 years after planting.

\begin{tabular}{lccc}
\hline Cultivar & ${\text { Vertical ht }(\mathbf{c m})^{\mathrm{z}}}$ & ${\text { Plant health rating }(\mathbf{0}-\mathbf{5} \text { scale })^{\mathrm{y}}}$ & Alive trees (\%) $^{\text {(\%) }}$ \\
\hline Fukunaga 1 & $273 \mathrm{a}^{\mathrm{x}}$ & $4.15 \mathrm{a}$ & $94 \mathrm{a}$ \\
Fukunaga 2 & $264 \mathrm{a}$ & $3.63 \mathrm{a}$ & $88 \mathrm{a}$ \\
Arnoldiana 1 & $255 \mathrm{a}$ & $3.81 \mathrm{a}$ & $100 \mathrm{a}$ \\
Arnoldiana 2 & $276 \mathrm{a}$ & $4.31 \mathrm{a}$ & $100 \mathrm{a}$ \\
Nemaya & $243 \mathrm{ab}$ & $3.03 \mathrm{ab}$ & $94 \mathrm{a}$ \\
Apoata & $205 \mathrm{~b}$ & $1.91 \mathrm{bc}$ & $81 \mathrm{a}$ \\
Purpurascens & $205 \mathrm{~b}$ & $1.50 \mathrm{~cd}$ & $69 \mathrm{a}$ \\
Kona Typica & $122 \mathrm{c}$ & $0.16 \mathrm{~d}$ & $19 \mathrm{~b}$ \\
\hline
\end{tabular}

${ }^{\mathrm{z}} 1 \mathrm{~cm}=0.3937$ inch.

${ }^{y}$ Plant health rating based on a scale of 0 to 5 , with 0 being morbid and 5 representing optimal health.

${ }^{x}$ Means with the same letter are not significantly different according to the Tukey-Kramer highly significant difference test $(P>0.05)$.
'Nemaya' rootstocks also had high survival rates, with $94 \%$ of trees remaining. 'Apoata' (81\%) and 'Purpurascens' $(69 \%)$ had lower survivability than others, with the nongrafted 'Kona Typica' having the lowest survivability at $19 \%$ (Fig. 1 ).

Cupping quality was unaffected by grafting on any of the rootstocks examined in this study, with cupping scores similar to those of nongrafted 'Kona Typica' (data not shown). Based on Specialty Coffee Association (SCA) protocols and a 100-point grading scale, blind cupping scores of the various treatments ranged from 81.00 to 83.75 , similar to those of nongrafted 'Kona Typica', which had a score of 83.50. The final SCA scoring rates these coffees as "Very Good Specialty" coffees.

\section{Discussion}

This study confirmed that kona coffee root-knot nematodes are a serious pest of 'Kona Typica' because they severely limit survivability, longevity, and yield potential in infested fields. During the 13 years since field establishment, coffee decline, caused by kona coffee root-knot nematodes, weakened 'Kona Typica' trees and caused high mortality. Yields were reduced at even greater levels than the reported $45 \%$ observed after a 2 year field trial (Schmitt et al., 2001) showing that damage from kona coffee root-knot nematodes is both $\mathrm{cu}^{-}$ mulative and irreversible. With no chemical or cultural method for eradicating kona coffee root-knot nematodes in infested fields, grafting has proven itself as the only viable cultural management practice for mitigating damage caused by nematodes. It is an effective technology that is economically viable, environmentally compatible, and easily adopted by growers.

Trees grafted on 'Arnoldiana' had the highest yields, health rating, and plant vigor comparable to 'Fukunaga', with no mortality after 13 years. The greatest amount of coffee cherry from an individual tree in the field was harvested from a tree grafted on 'Arnoldiana'. In addition, 'Arnoldiana' rootstocks had the highest yields of all the rootstocks tested when averaged over the entire pruning cycle. This cultivar shows promise as a new rootstock that can be incorporated into the long-term management of kona coffee root-knot nematodes in Hawaii. 
'Fukunaga' is currently used by some growers in Hawaii and is recommended by the University of Hawaii College of Tropical Agriculture and Human Resources (Bittenbender et al., 2001). It has been proven to be a reliable rootstock for use in commercial orchards infested with kona coffee root-knot nematodes, sustaining high yields, vigorous growth, and low mortality over a 13-year period. Necrosis was mild and few galls were observed on roots of 'Fukunaga' in contrast to severe necrosis and galling on 'Kona Typica' roots when inoculated with kona coffee root-knot nematodes in a potted plant bioassay (Cabos et al., 2010). Root weights and plant growth were also greater in infested 'Fukunaga' plants in contrast to infested 'Kona Typica'. A histology study showed fewer galls and poorly developed giant cells in liberica roots, suggesting a restriction in nematode development and reproduction (Arango et al., 1982). Liberica coffee was also found to have a more robust tap root that penetrated deeper in the soil profile than arabica root systems (Bertrand et al., 2001). The ability of liberica coffee to produce new roots even in the presence of high nematode population densities makes it an effective rootstock (Cabos et al., 2010).

Although it performed well in the initial years of the trial, 'Purpurascens' fared poorly in this long-term study, with low yields, poor health, and $31 \%$ mortality. As observed with other arabica cultivars like Kona Typica, the inability to produce vigorous roots in the presence of a nematode infestation makes it highly intolerant to kona coffee root-knot nematodes.

Although 'Apoata' is successfully used as a rootstock against root-knot nematodes in Brazil (Campos and Villain, 2005), it did not perform well against kona coffee root-knot nematodes in this study. This further justifies the importance of screening multiple coffee species against local nematode isolates to find the optimal rootstock for that region.

'Nemaya' rootstocks demonstrated greater yields and less mortality than nongrafted 'Kona Typica', but they were not as productive or healthy as the liberica cultivars. High variability among individual trees suggests outcrossing and genetic variation, as seen in a previous potted plant bioassay (Cabos et al., 2010). To maintain nematode tolerance, clones should be made by selecting robusta trees that remain vigorous (Fatobene et al., 2018). Even variations among accessions of both liberica cultivars require further study and consideration when selecting material for distribution to growers.

The presence of naturally occurring arbuscular mycorrhizal fungi (AMF) in the field plot could also explain some of the variation. The AMF compete with nematodes for space and nutrients and improve plant tolerance by increasing root vigor (Schouteden et al., 2015). When mycorrhizal root exudates in the soil were encountered, root-knot nematode motility and root penetration were reduced (Vos et al., 2012). Inoculation of coffee seedlings with AMF in a greenhouse bioassay demonstrated increased tolerance and reduced damage from parasitism by root-knot nematodes (Alban et al., 2013). Subsampling from the field plot revealed AMF colonizing 23\% of the tree roots. Colonization of all and productive in infested fields

the trees sampled was not observed for any one cultivar, and no AMF were found to be associated with Kona Typica. The dataset was insufficient to draw any conclusions at this time, but future research of the role of AMF in the tolerance of coffee cultivars to kona coffee root-knot nematodes should be explored.

Due to its isolated location, Hawaii has few of the diseases and pests plaguing most coffee-growing regions. Kona coffee root-knot nematodes are likely the most significant contributor to declining yields in Kona orchards. With high nematode populations in the field, symptoms of coffee decline, and no other observable biotic or abiotic factors, it is reasonable to conclude that the differences in health and yield of the grafted trees were due to the varying levels of tolerance to kona coffee root-knot nematodes by the rootstocks.

There is a need to continue outreach efforts to educate growers regarding the adverse effects of kona coffee root-knot nematodes on coffee production. Lack of awareness of the existence of this pest has resulted in

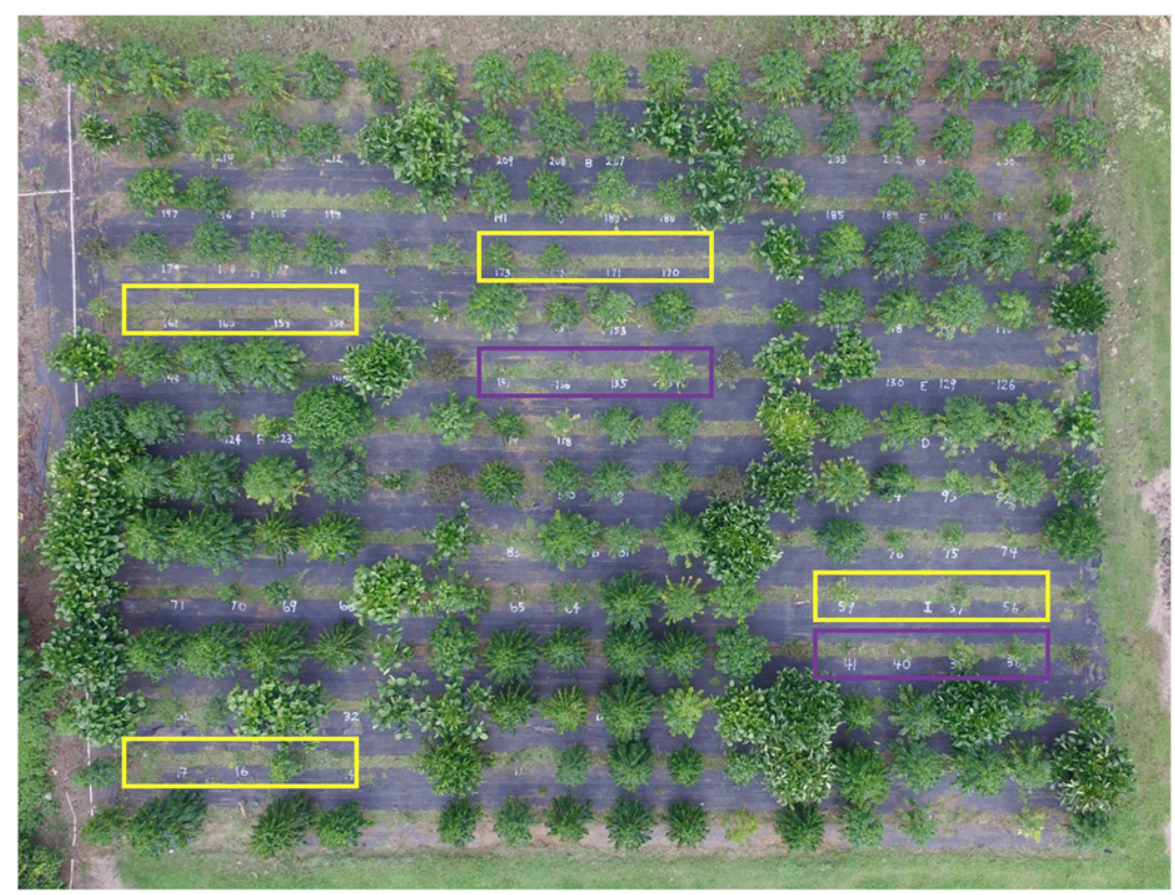

Fig. 1. Aerial view of a 13-year-old field containing 'Kona Typica' arabica coffee grafted on root-knot nematode-tolerant rootstocks of liberica, robusta, and arabica coffee and nongrafted 'Kona Typica'. Blocks consist of four grafted trees bordered on each side by nongrafted rootstock cultivars. Boxes highlight low survivability in blocks of nongrafted 'Kona Typica' (yellow) and 'Kona Typica' grafted on 'Purpurascens' (purple). 
a continuing, but not well-documented, decrease in yields. Increased availability of rootstock material needs to be addressed with careful selection and clonal propagation of high yielding and highly tolerant accessions.

Grafting 'Kona Typica' onto 'Arnoldiana' and 'Fukunaga' rootstocks when establishing or replanting coffee orchards in Hawaii can be an effective long-term solution to managing kona coffee root-knot nematode infestations. The initial cost of investing in nematode-tolerant plant material will be offset by improved longevity and higher yields. If this practice is adopted, then no additional control methods for kona coffee root-knot nematodes will be necessary for the life of the tree. With its outstanding vigor and production rate, 'Arnoldiana' can be recommended for use as a rootstock alongside 'Fukunaga'.

\section{Literature cited}

Alban, R., R. Guerrero, and M. Toro. 2013. Interactions between a root-knot nematode (Meloidogyne exigua) and arbuscular mycorrhizae in coffee plant development (Coffea arabica). Amer. J. Plant Sci. 4:19-23.

Andreazi, E., G.H. Sera, R.T. de Faria, T. Sera, I.C.B. Fonseca, A.C.Z. Machado, L.H. Shigueoka, F.G. Carvalho, and F.C. Carducci. 2015. Behavior of 'IPR 100' and 'Apoatã' coffee cultivars under different infestation levels of Meloidogyne paranaensis inoculum. Austral. J. Crop Sci. 9:1069-1074.

Arango, L.G.B., A.C.C. Baeza, and J.E.C. Leguizamón. 1982. Pruebas de resistencia a especies de Meloidogyne spp. en plántulas de Coffea spp. Proc. 10th Intl. Sci. Colloq. Coffee, 11-14 Oct. 1982, Salvador, Brazil. p. 563-568.

Barbosa, D.H.S.G., H.D. Vieira, W.P. Rodrigues, J.C. Rodrigues Filho, D.G. Barroso, and T.R.C. Silva. 2014. Efeito da enxertia e do nematoide Meloidogyne exigua sobre o crescimento radicular e a produtividade de cafeeiros. Coffee Sci. 9:427-434.

Barros, A.F., R.D.L. Oliveira, I.M. Lima, R.R. Coutinho, A.O. Ferreira, and A. Costa. 2014. Root-knot nematodes, a growing problem for Conilon coffee in Espírito Santo state, Brazil. Crop Prot. 55:74-79.

Bertrand, B., H. Etienne, and A. Eskes. 2001. Growth, production, and bean quality of Coffea arabica as affected by interspecific grafting: Consequences for rootstock breeding. HortScience 36:269273.

Bertrand, B., M.X. Peña Durán, F. Anzueto, C. Cilas, H. Etienne, F. Anthony, and A.B. Eskes. 2000. Genetic study of Coffea canephora coffee tree resistance to Meloidogyne incognita nematodes in Guatemala and Meloidogyne sp. nematodes in El Salvador for selection of rootstock varieties in Central America. Euphytica 113:79-86.

Bittenbender, H.C., D.P. Schmitt, M. Serracin, and C.G. Cavaletto. 2001. Fukunaga, a coffee rootstock resistant to the kona coffee root-knot nematode. Univ. Hawaii Manoa, College Trop. Agr. Human Resources, New Plants for Hawaii NPH-6. 29 Nov. 2019. <http://www. ctahr.hawaii.edu/oc/freepubs/pdf/ NPH-6.pdf>.

Cabos, R.Y.M., B.S. Sipes, C. Nagai, M. Serracin, and D.P. Schmitt. 2010. Evaluation of coffee genotypes for root-knot nematode resistance. Nematropica 40:191202.

Campos, V.P. and L. Villain. 2005. Nematode parasites of coffee and cocoa, p. 521-581. In: M. Luc, R.A. Sikora, and J. Bridge (eds.). Plant parasitic nematodes in subtropical and tropical agriculture. CABI, Wallingford, UK.

Eisenback, J.D., E.C. Bernard, and D.P. Schmitt. 1994. Description of the Kona coffee root-knot nematode, Meloidogyne konaensis n. sp. J. Nematol. 26:363-374.
Fatobene, B.J.R., V.T. Andrade, W. Gonçalves, and O.G. Filho. 2018. Coffee canephora clones with multiple resistance to Meloidogyne incognita and M. paranaensis. Exp. Agr. 55:443-451.

Kawabata, A.M., S.T. Nakamoto, and R.T. Curtiss. 2017. Recommendations for coffee berry borer integrated pest management in Hawaii 2016. Univ. Hawaii Manoa, College Trop. Agr. Human Resources, Insect Pests IP-41. 29 Nov. 2019. <https://www.ctahr.hawaii. edu/oc/freepubs/pdf/IP-4l.pdf>.

Reyna, E.H. 1966. Un nuevo método de injertación en café. Dirección General de Investigación y Control Agropecuario, Ministerio de Agricultura, Guatemala, Boletín Técnico No. 21.

Schmitt, D.P., F. Zhang, and M. Meisner. 2001. Potential for managing Meloidogyne konaensis on coffee in Hawaii with resistance and a nematicide. Nematropica 31:67-73.

Schouteden, N., D. De Waele, B. Panis, and C.M. Vos. 2015. Arbuscular mycorrhizal fungi for the biocontrol of plant-parasitic nematodes: A review of the mechanisms involved. Front. Microbiol. 6:1280, doi: 10.3389 /fmicb.2015.01280.

Serracin, M. and D.P. Schmitt. 2002. Meloidogyne konaensis and coffee rootstock interactions at two moisture regimes in four soils. Nematropica 32:65-76.

Serracin, M., D.P. Schmitt, and S. Nelson. 1999. Coffee decline caused by the kona coffee root-knot nematode. Univ. Hawaii Manoa, College Trop. Agr. Human Resources, Plant Disease PD-16. 29 Nov. 2019. <http://www.ctahr.hawaii.edu/ oc/freepubs/pdf/PD-16.pdf>.

Vos, C., S. Claerhout, R. Mkandawire, B. Panis, D. De Waele, and A. Elsen. 2012. Arbuscular mycorrhizal fungi reduce root-knot nematode penetration through altered root exudation of their host. Plant Soil 354:335-345.

Zhang, F. and D.P. Schmitt. 1995. Relationship of Meloidogyne konaensis population densities to coffee growth. Plant Dis. 79:446-449. 